\title{
9
}

\section{The Australian way of war and the early Cold War}

\author{
Peter J Dean
}

Is there an Australian way of war and, if so, how do Australia's military commitments in the early Cold War period map to this concept? These two questions form the fundamental basis of the concluding segment of this work. This chapter explores the conceptual notion of a 'way' or 'ways' of war in relation to Australia's strategic culture and military commitments in the period from 1945 until 1965. As the book has detailed, during this period Australia fought three conflicts - Korea, Malaya and Confrontation - and prepared to fight yet more in Indonesia, Papua New Guinea and across broader Southeast Asia. It demonstrates the importance of this period to Australia's, and the region's, security at a time of intense strategic competition.

This chapter will draw together these themes as well as situating the period of 1945-65 within the concepts of a strategic culture and a way of war. In particular, it will focus on exploring the genesis of British thinking in relation to their way of war. This is significant, not just in relation to Sir Basil Liddell Hart's pioneering work on the concept, but also due to the evolution of this concept in British strategic thinking and its parallels and applicability to the Australian context.

Context is critical. The manner in which Australia sought to achieve security during the early Cold War was part of a broader continuum of the Australian 'way(s) of war'. But like all epochs in history this was a period of both continuity and change. The period from 1945 to 1965 
saw Australia's strategic circumstances alter as the country sought to address its contemporary security concerns. The onset of the Cold War, decolonisation in Asia, the advent of nuclear weapons and the continued advancement of military technology all helped to reshape Australia's strategic environment. At the same time, many aspects of Australia's approach to conflict - and the preparations for potential conflict remained the same.

In attempting to reconcile the issues of strategic continuity, the Australian debate on a national way of war has, in many ways, paralleled many of the early debates on this concept that occurred in the United Kingdom. In particular, the traditional notion of an Australian way of war is overwhelmingly shaped by a false dilemma or dichotomy - the choice between either a continental defence (Defence of Australia, or DoA) or an expeditionary approach to Australian strategy - which similarly plagued early discourses on the British way of war.

\section{Strategic culture and a way of war}

Like any conceptual or theoretical approach, there is a plethora of criticism of attempts to outline a national way, or ways, of war and much ink has been spilt debating the relative merits of a way of war as a frame of analysis. Of particular note is the use of a way of war less often as a frame for historical analysis of complex events and more as a political tool grounded in a form of policy advocacy. This criticism casts its way back to the field's foundational work, Sir Basil Liddell Hart's The British way in warfare.

While Liddell Hart's pioneering analysis dates from the 1930s, it was not until the 1970s that debate in international relations and strategic studies delved into a broader capstone concept: the idea that nation states have a strategic culture. Strategic culture has proven to be even more multifarious

1 Basil H Liddell Hart, The British way in warfare (London: Faber \& Faber Ltd, 1932). Such debate is not restricted to Britain but occurs for each country on which studies have been based. For Australia some key texts include: Michael Evans, The tyranny of dissonance: Australia's strategic culture and way of war 1901-2005, Study Paper No. 306 (Canberra: Land Warfare Studies Centre, 2005), at: researchcentre.army.gov.au/sites/default/files/sp306_tyranny_of_dissonance-michael_evans.pdf; David Kilcullen, 'Australian statecraft: The challenge of aligning policy with strategic culture', Security Challenges 3, no. 4 (2007): 45-65; Peter J Dean 'The alliance, Australia's strategic culture and way of war', in Australia's American alliance, ed. Peter J Dean, Stephan Frühling, and Brendan Taylor (Melbourne: Melbourne University Press, 2016), 224-50. 
than a national way of war, and in the academy even more controversial. Pioneered by the then Rand analyst Jack Snyder, and investigated deeply by scholars such as Ken Booth, Colin Grey and Alistair Ian Johnson, ${ }^{2}$ this concept, like a way of war, has eluded precise definition and gone through various iterations of construction and theoretical interpretation. To choose just one, somewhat contemporary, definition, Kerry Longhurst has proposed that a strategic culture is:

a distinct body of beliefs, attitudes and practices, regarding the use of force, which are held by a collective [usually a nation] and arise gradually over time through a unique protracted historical process. ${ }^{3}$

Scholars generally regard 'a way of war' as a subset of a nation's strategic culture.

Conceptually, a way of war is more grounded in military history. As Tony Echevarria has argued, 'we can only know a way of war historically by piecing together what has been done'. 'Thus the concept can be conceived as a 'historical pattern or tradition reflecting how and why force has been used'.

Thus the two concepts, strategic culture and a way(s) of war, are both useful in their own right but are better understood in terms of their interrelationship. As Lawrence Sondhaus has outlined:

for the political scientist, the true utility of strategic culture lies in how it can help us understand observed behavior in the present (rather than to predict future behavior), for the historian of war and diplomacy [a way of war] offer[s] a useful framework for understanding the recent as well as the more distant past. ${ }^{6}$

2 See Ken Booth and Russell Trood, Strategic cultures in the Asia-Pacific region (London: MacMillan, 1999); Lawrence Sondhaus, Strategic culture and ways of war, Cass Military Studies (London: Routledge, 2006); Alastair Iain Johnston, 'Thinking about strategic culture', International Security 19, no. 4 (1995): 32; Alastair Iain Johnston, Cultural realism: Strategic culture and grand strategy in Chinese history (Princeton: Princeton University Press, 1995); Colin S Gray, 'Strategic culture as context: The first generation of theory strikes back', Review of International Studies 25, no. 1 (1999): 49-69, doi.org/10.1017/s0260210599000492; Colin Grey, 'Strategy and culture', in Strategy in Asia: The past, present, and future of regional security, ed. Thomas G Mahnken and Dan Blumenthal, Stanford Security Studies (California: Stanford University Press, 2014), doi.org/10.1515/9780804792820.

3 Kerry Longhurst, Germany and the use of force: The evolution of German security policy 19902003 (Manchester: Manchester University Press, 2004), 17.

4 Antulio J Echevarria II, Reconsidering the American way of war: US military practice from the Revolution to Afghanistan (Washington DC: Georgetown University Press, 2014), 176.

5 Max Boot as cited in Echevarria, Reconsidering the American way of war, 19.

6 Sondhaus, Strategic culture and ways of war, 13. 


\section{Liddell Hart and the British way of war}

Liddell Hart's original work was the conceptual birth of a 'way of war' in the academy. ${ }^{7}$ Central to Liddell Hart's thesis was the case that strategic debates in the United Kingdom were best understood as a fundamental dilemma between continental and indirect (or navalist) approaches to strategy; whereby the British had to constantly balance European continental commitments against imperial commitments. For Liddell Hart, the one true approach to British strategy was the indirect approach. He argued that the 'misguided' decision during the First World War to purse a continental strategy over an indirect strategy was in contravention to the traditional British 'way of war'. ${ }^{8}$

Liddell Hart's argument was a direct response to the attrition-based warfare that characterised the Western Front from 1914 to 1918 and the subsequent losses suffered by Great Britain. This was a deeply personal experience for Liddell Hart who had served as a captain in the King's Own Yorkshire Light Infantry Regiment on the Western Front. Liddell Hart saw the British commitment of a large continental army to Europe and the subsequent loss of life as a result of 'shallow thought ... deformed by slavish imitation of Continental fashions' by the British Government. He worried that the movement away from a 'navalist' strategy based on the indirect approach was 'stunted by the consequences of that malformation are to be found in the years 1914-1918 and have been felt ever since'. ${ }^{9}$

7 The use of 'ways of war' relates to a nation's grand strategic approach to the use of military force. As such, this chapter defines a 'way of war' as the way and manner in which a military force is used by a nation state at the grand strategic level as part of its strategic culture. A way of 'warfare' is a type of military approach to operations adopted by a nation's military services to meet the strategic challenges it is faced with. A 'way of warfare' or 'warfighting' is, as David Horner has noted, the 'way a nation and its armed forces fights its wars' (emphasis added). See David Horner, 'The Australian way of warfighting', paper presented to the Australian Command and Staff College, Queenscliff, 24 June 1996. Such a view was standard in British Commonwealth doctrine and manuals: e.g. combined or amphibious operations are referenced to as a 'form of warfare'.

8 Liddell Hart, The British way in warfare.

9 Ibid., 7. 


\section{Liddell Hart and the conceptualising of the 'Australian way of war'}

At the centre of Liddell Hart's analysis was the presentation of a dilemma between two approaches to strategy: a European continental strategy versus an indirect, maritime approach. A similar dichotomy has been the intellectual foundation from which debates on Australia's way of war have also evolved. ${ }^{10}$ At the heart of the current Australian conceptualisation of a 'way of war' is a debate between those favouring an expeditionary approach to the use of military force in support of Australia's major power allies, versus those favouring a focus on the continental defence of the Australian mainland. While this Australian discourse has attracted only a small number of commentators and academics, the basic approach is characterised by this bifurcation. It is led by the two most prolific writers and policy advocates for each camp: Michael Evans (expeditionary) and Hugh White (continental or DoA).

The most prodigious writer on the Australian way of war has been Professor Michael Evans. In Evans's seminal work on the topic, The tyranny of dissonance: Australia's strategic culture and way of war 1901-2005, ${ }^{11}$ he argued that the divide between expeditionary and continental approaches has personified Australian debates over strategy since Federation in 1901. Evans has argued even more directly and succinctly in the public sphere about the Australian way of war. In 2003, at the time of Australia's involvement in the controversial war against Iraq, he argued that:

Effectively then, the Australian way of war has been based on fusing strategy and statecraft through the agency of expeditionary warfare using volunteer forces in coalition operations. In all of these struggles, the Anzac tradition has acted as an important conduit for the interpretation of Australian democratic national values - pragmatism, fairness, egalitarianism and mateship within an alliance warfare setting. ${ }^{12}$

10 This debate in Australia has been driven by Australia's strategic circumstances, especially its geography, rather than a case of replicating a British strategic debate for antipodean needs.

11 Evans, The tyranny of dissonance.

12 Michael Evans, 'Values are our frontier', The Australian, 11 November 2003. 
Former senior defence official, and one of the nation's leading public intellectuals on defence, Professor Hugh White agrees with Evans that the Anzac tradition has played a seminal role in the Australian way of war and defence policy. White noted in 2007 that Evans's interpretation was one also shared by the prime minister of the day, John Howard, whereby:

our way of war is to send armed forces to support our allies in major land operations anywhere in the world in which our shared interests (often described as our 'values') are threatened ... [and that this approach] is supposed to guarantee that threats closer to home never emerge. ${ }^{13}$

To White, this way of war is one driven by a conceptualisation of Australia's alliances as a form of collective defence. White sees this approach to Australia's major power alliances as a particular form of collective security, one reminiscent of a type of security banking credit system - whereby Australia pays into a security account with a major ally. This is achieved by Australia supporting her great and powerful friends in distant offshore conflicts aligned with Australia's values in order to 'bank' security credits that Australia would be able to draw upon in conflicts or security concerns closer to home. ${ }^{14}$

White is, however, critical of this approach - seeing an expeditionary way of war as focused on the past rather than the future of Australia's security needs. In addition, he further refines this approach as being part of a tradition centred on the Australian Army's approach to warfare. This approach, he argues, is in opposition to the other tradition in Australian defence policy - continental defence. ${ }^{15}$ From the period of the mid-1970s, the continental defence tradition was conceptualised as Defence of Australia (DoA), underpinned by the idea of self-reliance within the US alliance framework. ${ }^{16}$ White's critique thus sits at the centre of the expeditionary versus continental divide that has dominated so many of the debates around Australian defence policy from the 1970s into the 2000s.

13 Hugh White, 'Anzac, our Achilles heel?', The Age, 24 May 2007.

14 This is not too different from the idea of past actions theory as a way of assessing military threats. See Daryl Press, Calculating credibility: How leaders assess military threats, Cornell Studies in Security Affairs (Ithaca: Cornell University Press, 2005).

15 White, 'Anzac, our Achilles heel?'.

16 Stephan Frühling, 'Australian defence policy and the concept of self-reliance', Australian Journal of International Affairs 68, no. 5 (2014): 531-47, doi.org/10.1080/10357718.2014.899310. 
The one common feature of both Evans's and White's work is the centrality of Australia's alliance relationships to its way of war. ${ }^{17}$ The alliance basis to the Australian way of war is widely recognised. One of Australia's leading political journalists and commentators, Paul Kelly, noted in 2002:

for half a century the Australian way of war has been obvious: it is a clever, cynical, calculated, modest series of contributions as part of US-led coalitions in which Americans bore the main burden. This technique reveals a junior partner skilled in utilising the great and powerful in its own interest while imposing firm limits upon its own sacrifices. It is one reason the alliance is so popular. ${ }^{18}$

Agreement on this aspect of the Australian way of war is emblematic of the dominance of an alliance-based approach to Australia's strategic culture.

\section{Australia's strategic culture}

An alliance with a great and powerful friend has been the dominant approach to Australian strategic culture since the period before Federation. However, this is not to say that an alliance-based strategic culture is exclusive. The best way of understanding the dynamics of a strategic culture, especially when accounting for both continuity and change in this concept, is to understand it through the lens of a series of competing subcultures that vie for dominance over strategic policy. ${ }^{19}$

Throughout Australian history the competing subcultures in Australian strategy have included great power alliance, unarmed and neutral, armed neutrality (often also called 'armed and independent'), and a 'fortress Australia' approach. ${ }^{20}$ These approaches to strategy have, at various times, battled for influence over Australian strategic policy - indeed, contemporary debates over the direction of Australian strategy in response

17 In his most recent work, White argues for 'strategic independence', i.e. the ending of the alliance with the United States and the movement to what could be termed armed neutrality. See Hugh White, How to defend Australia (Melbourne: Black Inc., 2019).

18 Paul Kelly, 'No lapdog, this partner has clout', The Australian, 28 August 2002.

19 Alan Bloomfield, 'Time to move on: Reconceptualizing the strategic culture debate', Contemporary Security Policy 33, no. 3 (2012): 437-61, doi.org/10.1080/13523260.2012.727679.

20 See Dean, 'The alliance, Australia's strategic culture and way of war'; and Peter J Dean, 'Armed neutrality: Dependence, independence and Australian strategy', in After American primacy: Imagining the future of Australia's defence, ed. Peter J Dean, Brendan Taylor and Stephan Frühling (Melbourne University Press, Melbourne, 2019). 
to the rise of China and the relative decline of the United States has seen a resurgence of an argument advocating armed independence, led by Hugh White. ${ }^{21}$

However, despite the at times spirited debates over Australian strategy, the alliance subculture has dominated strategic policy. This dominance has been driven by a succession of governments, supported by policy elites, who have assessed Australia's relative position in the region and the world, as well as the material difficulties of self-defence, and have concluded that an alliance with a great and powerful friend is far and away the least costly approach economically, as well as providing materially more security. Thus, the main strategic debates in Australia since Federation have principally evolved around the balance between engagement and dependence with Australia's major alliance partners and the desired level of 'self-reliance' within the alliance (as opposed to self-sufficiency). This is what has largely driven the characterisation of the Australian way of war debate and the dichotomy between expeditionary versus continental defence approaches - both of which support the alliance-based strategic culture; a position deeply at play in the period of 1945-65 as Australia was engaged in Commonwealth defence efforts while also developing a new alliance with the United States.

\section{Paralleling the British: The Australian 'dilemma'}

Liddell Hart's thesis on the British way of war remained largely unchallenged until the 1970s, although international relations theorist John Mearsheimer has suggested that it was a 'short lived idea ... lasting from around 1931-1933' as it paid little interest to changes in naval power in the latter half of the 1930s. ${ }^{22}$ However, the popularity of Liddell Hart's thesis persisted well after its initial publication. The book was reprinted in 1941 and again in 1976 and, although Liddell Hart never revisited the concept in any other publication, it survives as a model and the genesis for subsequent conceptual works.

21 White, How to defend Australia.

22 Mearsheimer as quoted in Sondhaus, Strategic culture and ways of war, 2. 
From the mid-1970s, Liddell Hart's work started to attract much greater academic attention and soon thereafter it was subjected to major criticism and revision by many leading British military historians of the time. One of the first major criticisms came from Sir Michael Howard. In a lecture at University College London in 1974, Howard was unstinting in his forensic analysis of Liddell Hart's work. Howard noted that Liddell Hart's

analysis of British strategy was nothing more than a piece of brilliant political pamphleteering, sharply argued, selectively illustrated, and concerned rather to influence British public opinion and government policy rather than to illuminate the complexities of the past in any serious or scholarly way. ${ }^{23}$

Extrapolating on this line of analysis, Andrew Lambert noted in 2010 that Liddell Hart's thesis is 'a dogmatic prescription' of Julian Corbett's Some principles of maritime strategy, which itself should be only seen as 'the opening essay of an ongoing debate' and as a 'basic analytical tool'. ${ }^{24}$ David French's 1990 monograph of a similar name, The British way in warfare, 1688-2000, argued that British governments had, in fact, concentrated on pursuing the country's strategic interests above all else, alternating between maritime and continental approaches to strategy as the circumstances dictated. The defining characteristic, he noted, was the emphasis on minimising cost. ${ }^{25}$ Thus, the British way in warfare was neither navalist as Liddell Hart claimed, nor mixed in its approach as others have claimed, but 'essentially adaptive'. ${ }^{26}$

In a similar vein to Liddell Hart's original thesis, most commentators in Australia have applied the reductionist approach: posing a dilemma between expeditionary operations in support of distant allies versus the continental defence of Australia. ${ }^{27}$ The parallel between the Australian debates and the original controversy over Liddell Hart's thesis is unmistakable. This is the key feature of both Evans's and White's assessments and it is core to

23 Michael Howard, The causes of wars and other essays (Cambridge, Massachusetts: Harvard University Press, 1983), 172.

24 Andrew Lambert, 'The naval war course', in The British way in warfare: Power and the international system, 1856-1956: Essays in honour of David French, ed. Keith Neilson and Greg Kennedy (Ashgate: Routledge, 2010), 250-51.

25 David French, The British way in warfare, 1688-2000 (London: Routledge, 1990); see also Neilson and Kennedy, The British way in warfare: Power and the international system, 1856-1956: Essays in honour of David French.

26 French, The British way in warfare, 1688-2000, 23.

27 For the discussion of British defence policy in the twentieth century and his 'dilemma', see Hew Strachan, 'The British way in warfare revisited', The Historical Journal 26, no. 2 (1983): 447-61. 
the ideas of other commentators in this debate such as Paul Kelly and John Birmingham, and academics such as Alan Bloomfield, Victor Nossal, Alex Burns and Ben Eltham. ${ }^{28}$ Most significantly, both Evans and White used their characterisation of an Australian way of war as a foundation for their policy advocacy.

Evans, in the early 1990s, aimed to support the Australian Army's attempts to address what it saw as the limitations of the DoA policy. In the early 2000s, Evans also saw his interpretation of the Australian way of war as a way to support the Australian Government's commitments to the wars in the Middle East based, in part, on the continuity of this approach with Australia's traditional use of military force.

White's characterisation of an Australian way of war was used to highlight the expeditionary approach as outdated and relevant only to Australia's past rather than its strategic future. His focus was squarely on the centrality of the DoA concept. This binary divide and positioning of Australia's way of war as a core component of contemporary policy debates means that Australia's use of this concept has been largely captured in the same conceptual problems that beleaguered Liddell Hart's original work.

Moving beyond a binary approach has been the key to the modern British debate on their way of war. As Correlli Barnett has argued, 'it is a mistake to subscribe to either [British] school [maritime or continental] in its full doctrinal rigidity. All depends on particular cases'. ${ }^{29}$ Brian Bond has noted that for the period in which Liddell Hart first outlined the concept, between the two world wars, continental and maritime strategies for the British were complementary not alternative strategies. ${ }^{30}$ To Hew Strachan the choice [for the British] between the maritime and the continental strategies is, in historical terms, a false one' ${ }^{31}$

28 John Birmingham, A time for war: Australia as a military power, Quarterly Essay No. 26 (Melbourne: Black Inc., 2005); Alan Bloomfield and Kim Richard Nossal, 'Towards an explicative understanding of strategic culture: The cases of Australia and Canada', Contemporary Security Policy 28, no. 2 (2007): 286-307, doi.org/10.1080/13523260701489859; Alex Burns and Ben Eltham, 'Australia's strategic culture: Constraints and opportunities in security policymaking', Contemporary Security Policy 35, no. 2 (2014): 187-210, doi.org/10.1080/13523260.2014.927672.

29 Correlli Barnett, Britain and her Army, 1509-1970: A military, political and social survey (London: Allen Lane, 1970), xviii as quoted in Strachan, 'The British way in warfare revisited', 455.

30 Brian Bond, British military policy between the two world wars (Oxford: Clarendon Press, 1981), 1.

31 Strachan, 'The British way in warfare revisited'. 
For Michael Howard, the debate is actually about the nuances of strategy, and the 'British dilemma' should not be seen as a reductionist either/or strategic approach, but rather a relationship of interdependence between the command of the seas and the maintenance of a European balance of power. ${ }^{32}$ Howard's nuanced assessment is equally applicable to Australia's way of war - it should not be seen as a doctrinally rigid choice between the defence of Australia or expeditionary approaches to strategy.

\section{Beyond the false dilemma}

The key to understanding Australia's way of war is to understand the complex set of calculations that drove the development, and constant revision, of Australia's strategic policy. This means it bears much more in common with the British way of war based on the analysis of French, Howard, Barnett and Strachan rather than the original, and rather limited, assessment of Liddell Hart. Ultimately, Australia's 'way of war' should be seen in terms of ways of war, in the plural sense. This is reflective of issues of both continuity and change in Australia's approach to strategy, which - like Great Britain's approach - has proven to be adaptive, defined by approaches to strategy that have been refined as circumstances dictated.

The key unifying element in the Australian example is its overriding preference for a strategic culture based on an alliance with a major power. Thus, Australia's ways of war are driven by a combination of the strategic circumstances of the country and its dominant strategic culture. In many senses, this too parallels the British experience. A defining feature of each country's ways of war is their relationship to respective major alliance partners. For the British, this was based around access to a continental-sized army in Europe to partner with its maritime power in order to affect the balance of power in Europe. During the First World War and 1939-40 this was France, thereafter it was a balance of France (1914-66) and the United States (1941-), then Germany (1966-) and the United States during the Cold War. ${ }^{33}$

32 Strachan, 'The British way in warfare revisited', 451.

33 Lawrence Freedman, 'Alliance and the British way in warfare', Review of International Studies 21, no. 2 (1995): $145-58$. 


\section{Australia's 'ways of war', 1945-65}

For Australia, material difficulties of continental defence, and the desire of a small to middle power to preserve the liberal international order in which it has prospered, has seen its major alliance partner shift from its colonial founder, Great Britain (1877-1942), to Great Britain and the United States (1942-68) and then the United States (1968-). As the introduction to this work notes, in contrast to popular imagination surrounding Prime Minister John Curtin's 1942 call to 'turn to America', Australian forces spent the best part of the following two decades closely integrated with the British and wider Commonwealth. From 1951, with the signing of the Australia, New Zealand and United States (ANZUS) Treaty, Australian strategy was built on balancing Australia's two great and powerful friends through a combination of Commonwealth defence, the US alliance and, for a short period, the Southeast Asia Treaty Organization (SEATO).

A key to understanding Australia's ways of war has been to understand the capabilities, interests and intents of its 'great and powerful friend(s)'. The vital element of this approach is to understand the role of Australia's major alliance partners in the context of global geopolitics and, especially, in their strategic approach to Australia's core areas of strategic interest: the South Pacific and Southeast Asia. ${ }^{34}$

Australian strategic history during 1945-65 amply demonstrates the need to move beyond the binary continental versus expeditionary debate. During this epoch, what emerges is the adaptability of Australian strategy, which derives a series of ways of war couched in the dominance of an alliance-based strategic culture. ${ }^{35}$ In this system, Australian strategic culture is dominated by twin needs: the desire for a long-term alliance with great powers, and a regional defence strategy focused on the South Pacific and Southeast Asia - areas that are generally very low-priority geographic regions for Australia's major alliance partners.

As Stephan Frühling notes in Chapter 1, the interrelationship between Australia's strategic interests and those of its major power allies is key. The period from 1945 to 1965 is where:

34 Peter J Dean, 'A new strategic song? ANZUS, the 2020 Australian defence update, and redefining self-reliance', War on the rocks, 12 August 2020, at: warontherocks.com/2020/08/singing-a-newstrategic-song-anzus-the-2020-australian-defence-update-and-redefining-self-reliance/.

35 The notion of understanding a nation state's ways of war is outlined in Matthew S Muehlbauer and David J Ulbrich, Ways of war: American military history from the colonial era to the twenty-first century (New York: Routledge, 2018), doi.org/10.4324/9781315545691. 
few certainties seemed to exist as Australia navigated its own particular version of the Cold War ... [especially as] the centre of gravity of the global Cold War lay elsewhere ... [and Australia's immediate geographic region] was nonetheless only of third-rate importance for Australia's [major power] allies.

During this period, the British Empire's intent and capabilities waned, while for the US peripheral theatres in the Cold War, like Southeast Asia, grew in importance as 1965 approached. As Tristan Moss demonstrates in Chapter 8, in the South Pacific meanwhile, both major powers showed little interest during a period of considerable Australian strategic concern. What is critical is the constant tension at the intersection of Southeast Asia and the South Pacific for Australia - the land border between Papua New Guinea and Indonesia and the constant tensions and difficulties in ANZUS over competing Australian and US interests.

\section{A coalition-focused way of war}

This means that Australia's ways of war during this period had two interrelated streams. The first is based around the use of force in coalition with Australia's great and powerful friends and generally consists of small (relative to the great powers), niche and largely single-service force commitments, generally dominated by the prominence of Australian land power. These forces are generally embedded into the forces of the larger ally and integrated into the larger ally's logistical system.

This approach has dominated Australian military history and seen the preponderance of Australian military power committed to the Middle East and Europe, but with episodic periods that focus on Asia, such as the period covered by this book. ${ }^{36}$ In this approach, Australia largely operates at two levels of war: ${ }^{37}$ strategic (decision to use force) and tactical (manoeuvres, engagements and battles that can be identified as a 'way of battle'). ${ }^{38}$

36 See Douglas E Delaney, The Imperial Army project: Britain and the land forces of the dominions and India, 1902-1945 (Oxford: Oxford University Press, 2018); Christopher Hubbard, Australian and US military cooperation: Fighting common enemies (Ashgate: Aldershot, 2005).

37 USAF College of Aerospace Doctrine, Research and Education (CADRE), 'Three Levels of War', in Air and Space Power Mentoring Guide, vol. 1 (Maxwell Air Force Base, Alabama: Air University Press, 1997), at: www.cc.gatech.edu/ - tpilsch/INTA4803TP/Articles/Three\%20Levels\%20of\%20War= CADRE-excerpt.pdf.

38 See Brian McAllister Linn, The echo of battle: The Army's American way of battle (Cambridge, Massachusetts: Harvard University Press, 2009). 
This approach is symbolic of Australia's engagement in conflicts of the colonial period, in which it raised forces to support the British Empire in the Maori Wars, the Sudan War, the Boxer Rebellion and the Boer War. It is also reflective of the use of Australian military force from 1915 to 1918 in the Middle East and on the Western Front. This approach was replicated with the decision to send part of 2 Australian Imperial Force to the Middle East and Mediterranean between 1940 and 1943, the deployment of significant elements of the Royal Australian Navy to operations in those theatres, and the support for the British Empire Air Training Scheme that saw thousands of Australian airmen serve in Europe and the Mediterranean right through until 1945.

The same principle was applied to the Korean War, although this was closer to home than the conflicts in the Middle East and Europe. The assault on Korea came as a surprise but it was soon evident that there was a clarity of interests and alignment with the United States. As Tom Richardson highlights in Chapter 4, the 'political climate [for] Australian participation in the Korean War was by no means guaranteed', given the focus on Southeast Asia; however, the Australian foreign minister saw it as a 'golden opportunity' to build 'political goodwill in Washington' to clear the way for an alliance with the United States.

Thus, Australia's commitment to Korea was driven by both the consideration of regional security and alliance management. The Korean War, with its supporting UN Security Council Resolution, also accorded with another of Australia's long-term, post-Second World War approaches to its grand strategy: a liberal institutional approach to diplomacy used to support the institutions that framed the so-called 'rules-based international order'. ${ }^{39}$

This approach, of using military force in support of Australia's great power ally and global security concerns, continued after the period of the Vietnam War - namely through Australia's commitment to the defeat of Saddam Hussein's occupation of Kuwait in the UN-sanctioned operations of the First Gulf War, and the reprise in 2003 during which a 'Coalition of the Willing' supported the overthrow of Saddam Hussein's regime in Iraq during the Second Gulf War. The onset of the Global War on Terror

39 Andrew O'Neil, 'Conceptualising future threats to Australia's security', Australian Journal of Political Science 46, no. 1 (2011): 19-34, doi.org/10.1080/10361146.2010.544286. 
after September 11, 2001 also saw Australia send military forces to fight in Afghanistan as well as forces to support the conflict against ISIS in Syria and Iraq. ${ }^{40}$

\section{A regionally focused way of war}

However, the limitations of Australia's alliance relationships, especially in its near region, have seen the development of a parallel approach to the Australian way of war built around the use of force by the Australian military in Southeast Asia and the South Pacific. This second stream approach is identified by the recognition that, for the majority of Australia's history, its two great and powerful friends have not shared the same levels of strategic interest in Australia's immediate geographical region.

This way of war has seen a lower frequency in the use of military force; however, given these regions' geographical proximity to Australia, the operations Australia has undertaken have arguably been of greater strategic importance than distant alliance deployments. This is largely due to these operations being undertaken in response to a perceived threat to the direct security of Australia and its immediate region, or in relation to Australia's unique strategic interests. The use of military force in these operations involves Australian commitment across all levels of war strategic, operational and tactical - with a heavier emphasis in the South Pacific on joint operations, either independently, semi-independently or in coalition.

A number of exceptionally important conflicts and operations in these regions across Australian military history have illustrated this way of war. Notable in this approach has been Australia's commitment to securing the approaches to the continent from the north-east, in particular the island of New Guinea. Australia's first major military commitment of the First World War, an often-overlooked operation, was the capture of German New Guinea in 1914 by a wholly Australian joint expeditionary operation. While also driven by imperial requests, the location of a German colony on Australia's doorstep was a major concern to the fledgling nation at the outbreak of war in 1914. Thereafter the defence of Australian New

40 These latter conflicts saw significant promotion of Australian military efforts through the commitment of Royal Australian Navy and Royal Australian Air Force units, which at times made up the majority of Australia's commitment. 
Guinea saw some of the most iconic battles of Australian military history fought on, above and around the island in 1942-44. Tristan Moss outlines in Chapter 8 the considerable commitment by the Australian military in the early Cold War to the defence of Australian territory in Papua New Guinea.

In the interwar period, Australia committed to the defence of both its immediate region and Southeast Asia via the Singapore strategy. With the advent of war with Nazi Germany and fascist Italy in 1939-40, Australia undertook multiple strategic approaches, including expeditionary deployments to the Middle East and Europe, regional deployments to Malaya, Singapore and the Dutch East Indies, and preparations for home defence.

The regional approach typifies the use of Australian military force during the early Cold War period. Early on, Australia assumed an expeditionary focus to strategic planning centred on the Middle East; but by the early 1950s, Australia left open the question of whether its forces would be sent to the Middle East or to Southeast Asia in the event of the Cold War turning hot. As Frühling notes in Chapter 1, by 1952-53 this emphasis had shifted to Asia and eventually Australia adopted an approach of seeking to have both Great Britain and the United States support the defence of Southeast Asia as a priority in a major global conflict.

Of course, preparation for conflict overseas was not the only thing on Australia's mind at the end of the Second World War. As John Blaxland and David Horner note in Chapters 2 and 3, Australia's largest-ever military commitment, the Pacific War, left a legacy that shaped the focus and direction of Australia's defence posture, force structure and military culture, and prompted an internal response through the establishment of the Australian Security Intelligence Organisation (ASIO) as the 'fourth arm of Australia’s defence'.

Nevertheless, the ink was hardly dry on surrender documents with Japan before Australia was yet again involved in regional military operations. Australia's first postwar commitment was to the Malayan Emergency. As Thomas Richardson outlined in Chapter 6, the commitment of Australian forces to Malaya, followed up with Australias work with Great Britain in the formation of the Far East Strategic Reserve (FESR), represented both Australia's attempts to resist communist aggression in the region and 'one of Australia's longest ... [regional] deployments'. 
Southeast Asia was a major region of focus for this period - driven by the power of geographic proximity. In Chapter 5, Tristan Moss outlines the extent of planning for the Cold War turning hot in Southeast Asia, a decade-long enterprise that focused Australia's regional military efforts. Despite debates in the 1950s over the relative importance of the Middle East, it became increasingly apparent that Australia must focus on regional efforts. Inside these developments was a constant reprioritisation driven by regional geopolitical developments, global politics and the often conflicting and competing demands of Australia's defence policy and posture as well as the demands of ANZAM (the Australia, New Zealand and Malaya alliance), the FESR and SEATO.

Two key conflicts in the region would cement Australia's geographic focus and its attempts to ensure that its major power allies remained fixed on regional developments in Southeast Asia: Confrontation and Vietnam. While Vietnam is deliberately outside of the scope of this book, as Moss states 'for a decade before the Vietnam War, Australia prepared to fight a conventional war in Southeast Asia ... [and] the FESR was ANZAM's contribution to SEATO ... that allowed it a seat at the planning table'.

Confrontation with Indonesia, as Lachlan Grant and Michael Kelly outline in Chapter 7, was intricately linked to both the US alliance and Australia's involvement in the war in South Vietnam. It also highlighted the fragility of over-reliance on great and powerful friends, as the United States consistently refused Australia's attempts to get clear commitments over Indonesia through the ANZUS Treaty. As James Curran's work Unholy fury highlights, 'perhaps the most dramatic manifestation of the limits to rhetoric of shared values and common interests [in the ANZUS alliance] was made over the question of Indonesia. ${ }^{41}$ Australia's constant search for reassurances from the United States over Indonesia were rebuffed. While ambiguity within the wording of the ANZUS Treaty provided reassurance to the United States over possible entrapment by Australia in a conflict with Indonesia, it consequently stoked Australian fears of abandonment. Australian persistence was eventually met with a striking blow by President Kennedy, who noted to the Australian Minister of

41 James Curran, Unholy fury: Whitlam and Nixon at war (Melbourne: Melbourne University Press, 2015), 40 . 
External Affairs Garfield Barwick that 'people have forgotten ANZUS and are not at the moment prepared for a situation which would involve the United States'. ${ }^{42}$

The US response had far-reaching strategic consequences, helping to drive Australian engagement with the United States in the Vietnam War, while hedging through

substantially increased military expenditure, raising the strength of the regular army, purchasing 40 additional Mirage fighters, a third DDG, and ordering 24 F-111 bombers ... [to develop an] Australian capability to act independently of allies against Indonesia. ${ }^{43}$

As Grant and Kelly note, while ultimately the Australian and British response to Confrontation through Operation Claret 'remains a model of conducting a successful low-intensity conflict while maintaining diplomatic relations with the opposing nation', strategically it struck at the heart of Australian fears of US abandonment and thus the need for greater regional self-reliance.

This in turn shaped Australia's response to Vietnam. The Menzies Government aimed to provide a prompt gesture of combat support for Vietnam to generate goodwill towards Australia in Washington and to keep the United States engaged in the region. In addition, the provision of strong Australian diplomatic support to the United States and South Vietnam was aimed at hopefully 'obscur[ing] how small a military contribution Australia was capable of making'. ${ }^{44}$

Justified by SEATO and ANZUS, and spurred on by concerns stoked by the US response to Confrontation, the Australian Government committed advisers and later combat troops to Vietnam, premised on the idea that for a modest financial cost and a small commitment of forces Australia could draw the United States further into the defence of Southeast Asia. This strategy overlooked the nature of the conflict in South Vietnam, including the difficulties the United States would have in achieving a military outcome. Ultimately, the course of the war in Vietnam would lead to a US withdrawal from continental Southeast Asia, personified

42 Kennedy as quoted in Curran, Unholy fury, 44.

43 Stephan Frühling, A history of Australian strategic policy since 1945 (Canberra: Defence Publishing Service, 2009), 21.

44 Frank Frost, Australia's war in Vietnam (Sydney: Allen \& Unwin, 1987). 
by the declaration of the Nixon Doctrine in 1969 and the increasing Vietnamisation of the war in South Vietnam. These moves undermined the very basis of Australia's approach to regional security.

While Australia may have been largely focused on Southeast Asia in 1945-65, this did not stop the government from placing a high importance on the defence of the Australian mainland and the South Pacific. The South Pacific presents as peripheral to the bifurcation of the Australian way of war; however, it is exceptionally easy to view this region in a different light given the level of military commitment to the area throughout Australia's history. This is illustrated by major operations in New Guinea in the Second World War and deployments in the Cold War: operations Morris Dance (1987), Quick Step (2006) and Operation Fiji Assist (2016) in Fiji, deployments and operations in East Timor (1941-42, 1999, 2006), plus various deployments from the end of the Second World War through to today for humanitarian and disaster relief operations and peacekeeping/peace enforcement operations. ${ }^{45}$ The South Pacific has returned to focus through strengthened bilateral defence partnerships, the Pacific Patrol Boat Program and, from 2019, with the much-hyped federal government 'Pacific Step Up'. ${ }^{46}$

\section{Reconceptualising the Australian 'way of war'47}

These reflections on Australia's ways of war, concentrated on the period of the early Cold War, highlight the redundancy of the focus on a binary divide between the expeditionary and DoA schools of thinking on Australian strategy. Such a dualistic approach ignores the complexity and constant adaptability of Australia's approach to strategic policy. Conceptually, many of the operations in Southeast Asia in the period from 1945 to 1965

45 See Joanne Wallis, Pacific power? Australia's strategy in the Pacific Islands (Melbourne: Melbourne University Press, 2017); see also Dean, 'The alliance, Australias strategic culture and way of war', 242. 46 Prime Minister, Minister for Foreign Affairs, and Minister for Defence, 'Strengthening Australia's commitment to the Pacific', media release, 8 November 2018, at: www.pm.gov.au/media/strengtheningaustralias-commitment-pacific.

47 This argument has been outlined by the author in two other key assessments. See Dean, 'The alliance, Australia's strategic culture and way of war'; and Peter J Dean, 'Towards an Australian Marine Corps? Australian land power and the battle between geography and history', in A new strategic environment and roles of ground forces: NIDS international symposium (Tokyo: National Institute for Defense Studies, 2019). 
sit at the intersection of the expeditionary and DoA approaches, mixing together elements of both and forming what arguably could be labelled a third way of war for Australia: one focused on a regionalist approach.

In contemporary discussions of Australian strategy, some commentators have argued that a maritime strategy with a focus on the region is relatively new phenomenon: a 'third way' of thinking in Australian strategic policy, as manifested through the adoption of a maritime strategy for the Australian Defence Force and the revised focus of the 2009, 2013 and 2016 defence white papers. ${ }^{48}$ But as the chapters in this book have outlined, the period from 1945 to 1965 makes it clear Australia has a much longer and richer tradition in regional operations: it has always been there, as a consequence of the interplay of Australia's geopolitical circumstances and the fundamental tensions between Australia's interests in its region and those of its great and powerful allies.

The more regionalist approach placed a premium on Australia's middle power status with a pragmatic focus on the use of force not just for continental defence or expeditionary operations but throughout Australia's 'areas of direct military interest' - Southeast Asia and the South Pacific. Such an approach does not deride expeditionary concerns about the global balance of power, but is more pragmatic in its view of Australia's strategic weight and influence. Nor is it totally divorced from the idea of DoA - focusing as it does on operations closer to Australia's geographic centre of gravity. At times, it has provided for a more balanced approach to Australia's military structure and organisation, with an emphasis on capabilities that can be used throughout the region; an approach that was particularly influential in the late 1950s and 1960s and again during strategic guidance in the 1990s until the events of September 11, 2001.

These three ways of war have each held sway at different stages of Australian strategic history. However, what is critical to understand is that they were not rigidly adhered to in any one era and have been evident, in various forms, in all eras. What is central to understanding each of these

48 Michael Evans, The third way: Towards an Australian maritime strategy for the twenty first century, Australian Army Research Paper, no. 1 (Canberra: Australian Army, 2014). While Evans correctly positions the difficulties for Australia in developing a maritime strategy being a result of 'sea blindness' and Australia's reliance on the maritime supremacy of its great and powerful friends, he also attributes it to the 'schism between continental and expeditionary approaches in strategic behaviour' in Australia. 
conceptual approaches is the fundamental adaptability of Australian strategy, reflective of the pragmatic approach Australia takes to alliance management and regional and global security concerns.

Depending on dictates provided by Australia's strategic environment, each of these different ways of war have taken on different roles and places in Australian defence thinking. The period of 1945-65 is not only fascinating in its own right, but also informs contemporary debates. Then, as now, 1954-64 was a period defined by uncertainty, changing alliance structures, evolving threats, geopolitical change and great power competition.

Since the turn of the century, a layered approach, reflective of these three ways of war, has been evident in formal policy through the strategic objectives laid out in the 2000, 2009 and 2013 Defence white papers. These documents provided for a hierarchy of priorities based on DoA, then regionalism and finally global concerns. In the 2016 Defence white paper, these three strategic objectives continued to coexist but were placed on an equal footing. ${ }^{49}$

In response to the rise of China and the changing regional balance of power, Australian defence policy continues to adapt. The 2020 Defence Strategic Update outlined new strategic objectives: shape, deter and respond. In this approach, the centrality of the US alliance remains; however, the focus geographically is now the Indo-Pacific, defined as the region from the north-west Indian Ocean, through Southeast Asia to the South Pacific. Regionalism, it seems, is back in the ascendency in Australian strategic policy - just like it was in the period covered in this book. However, this does not totally ignore global security concerns, while at the heart of all Australian strategic policy documents sits the fundamental bedrock of the defence of Australia. The period of 1945-65 thus holds many important lessons for contemplation, for, as Mark Twain noted, while history may not repeat itself, it does rhyme.

49 Commonwealth of Australia, Defence white paper 2016 (Canberra: Australian Government Department of Defence, 2016), 69. 
This text is taken from Fighting Australia's Cold War: The Nexus of Strategy and Operations in a Multipolar Asia, 1945-1965, edited by Peter Dean and Tristan Moss, published 2021 by ANU Press, The Australian National University, Canberra, Australia.

doi.org/10.22459/FACW.2021.09 